\title{
COMO PENSAR?
}

Coordenador: Marco Aurélio Garcia (Secretaria Municipal da Cultura - São Paulo)

Expositores: Carlos Nelson Coutinho (UFRJ)

Fábio Konder Comparato (USP)

Francisco de Oliveira (USP) 



\title{
PENSAR COM RADICALIDADE E COM ESPECIFICIDADE
}

\author{
FRANCISCO DE OLIVEIRA
}

Minha saudação ao aniversário do CEDEC, que acompanho desde o nascimento e onde tenho grandes amigos. Com muito carinho e muita satisfação, vejo que esse centro continua impávido, dando uma notável contribuição a, exatamente, como pensar o Brasil.

Acho que não é muito difícil propor como pensar o Brasil, embora passar da sugestão para chegar a novas interpretações com poder explicativo seja uma tarefa hercúlea. São duas as condições que é preciso tomar em conta, seguindo a sugestão de Antonio Candido. A primeira, eu diria, seria pensar com radicalidade. É da tradição brasileira, como todos sabemos, o minueto intelectual na política, é até menos que um minueto porque é menos nobre. Na produção intelectual aí sim é o minueto a forma dominante: dois passinhos pra cá, dois pra lá, uma voltinha no meio, e assim o debate intelectual no Brasil é sempre - como Sérgio Buarque definiria - cordial, cordialidade no sentido forte. É um minueto em que os dois passinhos pra cá consistem numa compassividade acrítica, enquanto os dois passinhos pra lá desatam uma agressividade personalizada contra o que ousou discordar do consenso. É preciso outra vez romper com a cordialidade, com essa falta de radicalidade.

A segunda condição é de pensar a especificidade. Como a geração de 30 o fez. Como se deu a formação dessa sociedade, desse Estado; o que têm de próprio, de específico, de singular, evitando, evidentemente, a falsa autarquia, o isolamento das grandes correntes das ciências humanas e sociais em particular. Inscrita como especificidade no movimento mais geral do capitalismo, como fez Caio Prado Jr. e posteriormente Celso Furtado.

Temos bons exemplos. A geração de 30 aceitou o desafio de pensar o Brasil, com radicalidade e especificidade. Desde um Gilberto Freyre, nostálgico, conservador, melado de mel de engenho da cabeça aos 
pés. Entretanto, é forçoso reconhecer que Gilberto articula a denúncia mais vigorosa do que foi o escravismo, explicando-o até pelas relações sexuais, o que era um escândalo para a época e para as ciências sociais. Na linha de seu mais vigoroso inspirador, Joaquim Nabuco, a formação da sociedade é um estupro. Esse radicalismo, que é surpreendente quando se fala de um autor como Gilberto Freyre, e pensar o específico para alguém que vinha de uma educação protestante é de novo uma ousadia. Gilberto educou-se como um protestante, no Colégio Americano Gilreath em Recife. Depois completa sua formação na Inglaterra e nos Estados Unidos. Quem vai recuperar esse veio explicativo décadas depois é Richard Morse, que fará o elogio da miscigenação e da plasticidade católica, do iberismo para resumir. Acho que Gilberto constrói essa especificidade não abdicando, evidentemente, do seu patrimônio teórico/metodológico, para alguém criado e educado na tradição anglo-saxã, mas dentro dela ele acha um modo, surpreendentemente novo, de interpretar a sociedade brasileira.

O segundo da tríade, aquela nomeada por Antonio Candido, é precisamente Sérgio Buarque, que faz também um trabalho com o mesmo sentido de radicalidade e o mesmo sentido de especificidade. A radicalidade neste caso consiste precisamente em romper com o padrão cordial. Ao trabalhar o tema de uma sociedade patrimonialista, ele recusa o tratamento cordial, e ao contrário, acusa a chamada cordialidade brasileira como um problema e um estigma que acompanha a formação da sociedade, é sua própria estruturação e nos perseguirá, como provam os escândalos do Senado, por muito tempo. Escolhe um caminho que não se dilui na grande tradição da literatura patrimonialista, e encontra uma forma que é peculiar, extraída evidentemente do mundo ibérico, mas que no Brasil, com o cruzamento das tradições ibéricas com o escravismo como base do sistema produtivo - uma espécie de repetição da Antigüidade clássica -, ganhará um caráter muito particular. Logra a segunda grande feliz interpretação da sociedade brasileira nessa geração. Sérgio Buarque é possivelmente o único de nossos clássicos que aposta, decisivamente, na democracia.

O terceiro é Caio Prado, que navega num terreno mais ou menos infértil do ponto de vista do partido teórico que toma, ancorando-se no marxismo, numa cultura que não havia produzido até então nada muito inovador na utilização do ferramental marxista. Não se desconsidera aqui a luta política que operários e outros cidadãos haviam travado, pelo menos desde o começo do século, com as grandes greves, mas evidentemente a contribuição teórica para a ação prática foi muito minguada. Caio Prado, nesse terreno um tanto árido, elabora uma interpretação original, que bebia 
numa tradição historiográfica muito rica, desde o século XIX, com Taunay, Varnhagen, um Capistrano de Abreu, ao contrário da tradição que os grandes sociólogos e antropólogos como Gilberto e Sérgio herdaram. Não podiam absorver o que os clássicos do autoritarismo produziram, posto que para estes a "especificidade" brasileira era a bárbarie e a radicalidade era copiar o desenvolvimento europeu. Caio, ao contrário, com uma forte herança historiográfica onde se apoiar, forma toda uma escola de pensamento sobre a história brasileira que tem nele, com toda razão, seu patrono. O radical em Caio Prado Jr. será inscrever a história brasileira na história mundial: a colônia é uma obra da expansão capitalista e a ela estará ligada definitivamente. Combina-se em Caio o movimento geral da expansão capitalista e o "específico" nacional, que será o escravismo: enquanto no centro o capitalismo está liqüidando o trabalho servil, sua forma colonial assenta-se sobre o trabalho escravo.

$\mathrm{Eu}$ acrescentaria a essa tríade, para mostrar como trabalharam com radicalidade, com especificidade, Florestan Fernandes, em quarto lugar porque é de uma geração posterior à de 30 . Falo para um auditório que tem muitos formados pela USP, e para todos que conhecem a obra de Florestan. Talvez estejam conosco alguns dos melhores conhecedores da obra de Florestan. Minha leitura desta obra pode ser enviesada, mas para mim, até A revolução burguesa no Brasil, Florestan não havia produzido uma síntese de interpretação da história da formação da sociedade brasileira com o vigor da $A$ revolução burguesa. Todas as suas obras são, de alguma maneira, uma preparação para A revolução burguesa, mas acho que é com esse livro que ele logra, finalmente, entrar no panteão dos demiurgos do Brasil. De novo aí observa-se radicalidade. Talvez o livro mais radical dessa coleção de obras-primas seja A revolução burguesa, ao apontar os limites e os problemas da democracia numa específica periferia capitalista.

A eles eu acrescentaria Celso Furtado, pela contribuição à teoria do subdesenvolvimento. De novo aí temos radicalidade e especificidade. Radicalidade em romper com o padrão acomodatício da interpretação brasileira. Radicalidade em despojar-se de uma certa retórica comum ao pensamento social brasileiro, pelo menos até a geração de 30. Especificidade, que é o seu forte, precisamente porque, embora permaneça um certo dualismo na interpretação furtadiana, ele elabora uma interpretação singular, notável, que rompe tanto com o ramerrão das interpretações conservadoras, quanto rompe também, é forçoso reconhecer, com a incapacidade que o marxismo teve até aquela época de dar um salto até uma teoria que tratasse países da periferia com a complexidade exigida pela situação 
de ex-colônias. Furtado dá esse salto, que é precioso sob todos os pontos de vista, encontrando assim uma explicação que faz do subdesenvolvimento não um elo numa cadeia contínua entre o não desenvolvido e o desenvolvido, mas uma criação específica do capitalismo na sua periferia, no modo histórico portanto, e não uma sequiência de fases. Caio já havia sentado as bases para essa especificidade, mas é necessário reconhecer que seu trabalho é completado teoricamente por Furtado, que ajuda a criar uma nova categoria teórica para explicar um processo histórico novo, que não era, simplesmente, a extensão da colônia.

\section{DESAFIO MAIOR E MAIS COMPLEXO}

Esses cinco demiurgos fornecem a chave para pensar de novo com radicalidade e com especificidade. Não vale a pena e nem é produtivo, nem se chegaria muito longe, repetir a chave desses cinco grandes intérpretes. Eu diria que é o sentido com que elaboraram essas grandes interpretações o ensinamento para pensar uma situação nova, para uma nova complexidade, enfrentando desafios que não são mais os desafios do subdesenvolvimento, como por exemplo, ao me referir à obra de Furtado, enquanto um esforço de industrialização na periferia. Agora o desafio é maior, é mais complexo; não se trata só de industrializar. A inserção numa gama nova, mais densa, mais complexa, mais desafiadora, das relações internacionais, o que por economia de discurso podemos chamar de globalização, mas é necessário que aceitemo-la como desafio. Nesse momento a questão não é mais saber, como nos anos 30, se podemos ou não nos industrializar, nem se trata de perseguir a quimera de que a industrialização produziria novas relação sociais, produziria um novo padrão político no sentido da democracia liberal. Temos agora o direito a todas as dúvidas.

O desafio é também mais complexo porque o desenvolvimento capitalista não só rompeu em muitos sentidos as velhas estruturas patriarcais e patrimoniais, mas repôs, sob formas mais difíceis, mais intrincadas, tais estigmas. A indistinção entre público e privado continua e os escândalos de senadores estão aí só para confirma-las como regra e não exceção. O difícil é pensar agora essa trama de um capitalismo globalizado que torna funcional, pro domo suo, as práticas que numa perspectiva tipo "capitalismo e ética protestante" pareciam ser disfuncionais. Portanto, não se trata agora de repetir Gilberto ou Sérgio Buarque, mas de tomar suas indicações, que eu não chamaria propriamente de método porque todos são 
muito divergentes metodologicamente, e isso soa pedante, mas as indicações para tratar a nova complexidade. Mesmo a postura de Florestan, que foi mais longe na radicalidade, mesmo ela precisa ganhar nova densidade para avançarmos na interpretação da sociedade brasileira. Se já no seu trabalho os limites e problemas da democratização numa sociedade periférica apareciam bloqueados por uma espécie de permanente "via prussiana" ou "iberismo" como o Werneck Vianna tem elaborado, se já em Florestan esses limites apareciam, agora o problema repete-se como uma espécie de fuga para a frente, que terminou sempre, na história brasileira, em autoritarismos e em ditaduras. É importante não esquecer que nos 60 anos em que se celebra a industrialização nos padrões da segunda revolução industrial, nesses 60 anos de 1930 a 1990, este país foi governado durante 35 anos por ditaduras abertas, não disfarçadas, o que repõe o tema de Florestan com enorme força e, por que não dizer, com enorme pessimismo. Além disso, os 25 anos que sobram, deduzidas as ditaduras, fazendo-se as contas, foram marcados por tentativas de golpe a cada três anos.

\section{DECIFRAR DE NOVO A REPÚBLICA}

Se era assim até o momento em que a industrialização periférica, evidentemente ligada aos capitais internacionais e aos centros dinâmicos do capitalismo, já apresentava problemas para a democratização das relações sociais e para a democratização da sociedade, o que é que nos ocorre agora quando, nos termos de Celso Furtado, os mais importantes centros de decisão que haviam sido parcialmente internalizados nesses 60 anos de industrialização retornam quase que totalmente para o exterior? O tema volta com força, volta com propriedade. É preciso decifrar de novo esse enigma, decifrar de novo a república. Qual é, para dizer num termo caro aos economistas, qual é a produtividade teórica da república, o que ela nos ajuda a pensar o Brasil, ou ela é apenas uma figura e uma imagem? O que nos ajuda a pensar a Federação, acossada violentamente por uma integração subordinada à nova divisão internacional entre forças imperialistas. O que significa "federação"? O que significam as diferenças entre São Paulo e o Piauí? Uma federação pode resistir a essa tensão, de uma diferença de 10 para 1? A elaboração teórica e prática de um país que, corrijam-me todos os que aqui estão, que se faz federação sem federalistas, reparo que devemos ter em conta: falando dos clássicos demiurgos da interpretação brasileira, nenhum deles, 
salvo Celso Furtado, prestou atenção à questão da federação. A federação, do ponto de vista das ciências sociais brasileiras, das ciências humanas, não existe. Talvez eu que sou do Nordeste, talvez porque só olhamos para o próprio umbigo! Talvez porque, como dizia a oligarquia paulista até anos 30, talvez porque este país seja uma locomotiva puxando vagões vazios. Mas do ponto de vista da produtividade teórica para as ciências sociais, o que quer dizer federação no Brasil?

São temas, a meu modo de ver, que voltam com força, repõem problemas que as interpretações clássicas não haviam resolvido, mas haviam encaminhado admiravelmente. Com a vantagem de que dispomos hoje de uma enorme acumulação, de um patrimônio teórico, metodológico, muito mais rico, mais diversificado. Já a geração de 30 tinha uma vantagem sobre a geração anterior, que moldou também uma interpretação muito forte da sociedade brasileira, que permanece parcialmente até nossos dias. Quando o general Geisel dizia: "o povo ainda não pode votar, porque não está educado", ele ecoava estigmas apontados pela geração dos autoritários clássicos, segundo os quais um povo surgido de clãs bárbaras que se digladiavam numa tendência fortemente centrífuga só podia ser conformado por um Estado forte. Esse é todo o tema da ditadura.

Temos todas as vantagens do ponto de vista de patrimônio teórico, histórico, metodológico, sofisticação. Basta comparecer às reuniões das nossas principais associações científicas - para não permanecermos só nos nossos departamentos - para verificar que as ciências sociais brasileiras e as ciências humanas, de forma ainda mais ampla, estão ao compasso da produção teórica e metodológica mundial, com o avanço das pós-graduações, com o avanço do conhecimento de línguas, que permitiu entrar em contato direto com as fontes vindas de outras tradições culturais e teóricas.

Não podemos nos queixar do ponto de vista da mendicidade de nossos recursos teóricos interpretativos; pelo contrário, estamos mais preparados desse ponto de vista. Como diziam os evangélicos, é preciso aproveitar as riquezas da iniqüidade, e portanto, na tradição dos nossos cinco grandes demiurgos, retomar com radicalidade e trabalhar com especificidade. Isso é muito importante não apenas para nos regalarmos com as nossas próprias presentes, contemporâneas ou futuras criaturas. Isso é importante do ponto de vista cívico e importante do ponto de vista político. Podemos olhar ao lado e ver o desastre de políticas econômicas conduzidas, erguidas e trabalhadas sob a ótica da perda da especificidade. A mendicidade da política econômica é um decalque perfeito de qualquer manual da teoria econômica convencional. Segundo essa pobre e 
reducionista interpretação, que não é, a rigor, interpretação, havíamos ultrapassado o último piso do subdesenvolvimento e, portanto, as variáveis econômicas atuariam aqui como atuam em qualquer parte. Do ponto de vista teórico/metodológico essa é a essência da política econômica praticada hoje no Brasil, na Argentina e alhures, em quase toda parte. Só que na periferia, exatamente porque perdeu-se a capacidade de encontrar o que é específico de nossas sociedades, na América Latina e na África - que talvez esteja mais penalizada do que nós - essa teoria convencional que tornou-se pensamento único no mundo todo faz um enorme desastre.

\section{URGÊNCIA CÍVICA E POLÍTICA}

Portanto, pensar com radicalidade e com especificidade não é apenas para nos regalarmos com nossas produções teóricas; isso tem uma urgência cívica e uma urgência política, pois o efeito da negação da especificidade pode ser devastador, pensar sem radicalidade e sem especificidade, tal como a própria experiência latino-americana está mostrando e ainda com mais dor e com mais pesar a experiência africana. É a isso que estamos chamados. Eu espero que os 25 anos do CEDEC nos reanimem e nos lancem para frente nessa herança que recebemos e que às vezes mal soubemos reproduzir e ampliar. 



\section{SABER COMBINAR O ESPECÍFICO E O UNIVERSAL}

FÁBIO KONDER COMPARATO

Meus caros amigos, infelizmente há muito tempo que eu não tenho o prazer de ouvir Chico de Oliveira e conversar com ele. Foi uma grata surpresa, agora ouvindo-o, perceber que aquilo que ele havia preparado para dizer a todos nós corresponde, na substância e até em pormenores, àquilo que eu havia, de certa forma, preparado.

Existe, de certa maneira, entre pessoas preocupadas com o futuro do Brasil, um laço comum, uma espécie de lençol freático e que passa no subconsciente de todos nós e alimenta as nossas reflexões. O que me pareceu evidente quando eu comecei a pensar no tema é que nós precisaríamos, antes de mais nada, de um espírito crítico, no sentido etimológico da palavra. O verbo grego kriteô significa no seu sentido primitivo, joeirar, peneirar, e num sentido mais evoluído ele significa discernir. Aliás, do latim o kriteô deu cerno, raiz de discernir. Pois bem, houve um momento em que nós nos abrimos para o espírito crítico, porque redescobrimos o Brasil, e esse momento foi trágico, foi em Canudos. Eu, por acaso, topei com a citação de artigo de jornal de 1897, de Affonso Arinos de Mello Franco, naquela linguagem que Chico de Oliveira batizou de retórica bacharelesca. Ele nos diz o espanto que foi para todos os brasileiros tomar conhecimento da tragédia de Canudos. Diz ele: "o Brasil Central era ignorado. Se nos sertões existe uma população, dela nada conhece, dela não cura o governo". [como se o povo também não devesse se preocupar com o Brasil Central]. "E eis que ela surge numa estranha e trágica manifestação de energia, afirmando sua existência e lavrando com o sangue um veementíssimo protesto contra o desespero, o olvido a que foi relegada. Eles receberam o esplêndido e misterioso batismo de sangue e, tintos dessa púrpura, abriram as portas da nacionalidade brasileira a seus irmãos sertanejos". 


\section{A REDESCOBERTA DO BRASIL}

Foi, seguramente, no livro de Euclydes da Cunha, de 1902, que se abriu a consciência brasileira para a nossa realidade. Mas o pensamento nacionalista brasileiro só veio a ser elaborado a partir de 1922. 1922 é uma data simbólica. Comemorava-se o centenário da Independência, e foi a partir daí que a intelectualidade brasileira começou a pensar de forma independente. 1922, para recordar, foi o ano da Semana de Arte Moderna, da fundação do Partido Comunista e do nascimento do Movimento Tenentista, com o episódio dos 18 do Forte de Copacabana.

Essa redescoberta do Brasil foi feita por esses demiurgos de que falou Chico de Oliveira, principalmente a nossa tríade sagrada: Gilberto Freyre, Sérgio Buarque de Holanda e Caio Prado Jr.

O que eu gostaria de apontar agora, rapidamente, são exemplos de pensamento crítico entre esses redescobridores do Brasil, pensamento que combina a radicalidade com a especificidade, como disse Chico de Oliveira, ou seja, que sabe tomar das grandes correntes de pensamento aquilo que é útil e afastar aquilo que é inútil; sabe aplicar à realidade brasileira certas verdades comuns a toda a humanidade e pensar aquilo que entre nós é marcado pela especificidade.

Por exemplo, Caio Prado Jr. é o marxismo como método, mas nunca como explicação pré-moldada. Em nenhum momento da obra de Caio Prado Jr. se pode ver o decalque puro e simples do pensamento de Marx à realidade brasileira. Quando ele aponta o grande domínio rural escravista como a instituição central no Brasil durante mais de 3 séculos. Quando ele mostra que a sociedade brasileira foi durante séculos, e ainda é de certa maneira em alguns rincões do país, uma sociedade clânica e não classista; ou seja, uma sociedade que não conheceu o feudalismo e que passou diretamente do período clânico para o período de sociedade de classes, analisada pelo marxismo. A importância do clã patriarcal e a sua dimensão, digamos assim, decisiva na organização das relações sociais, na atividade econômica, na vida política. Toda análise marxista parte de uma sucessão do feudalismo e da sociedade de classes, mas nós nunca conhecemos essa sociedade estamental que marcou muito a Europa. Nós tivemos sempre, desde o início, uma sociedade de dominação, no sentido etimológico, ou seja, uma sociedade do senhor proprietário, e até hoje as nossas relações sociais são marcadas por essa dominação. Ainda em Caio Prado Jr., a análise do conflito que varou séculos no Brasil, entre comerciantes e proprietários rurais, como a réplica brasileira ao confronto entre nobres e burgueses na história européia. 
Se nós tomarmos um outro, já não digo demiurgo, mas enfim um grande pensador da realidade brasileira, o único não citado por Chico de Oliveira, Ignacio Rangel, nós vamos encontrar a mesma capacidade de análise crítica da nossa especificidade. Tal como Caio Prado Jr., Ignacio Rangel vem do marxismo, mas sempre soube utilizar o marxismo como método de análise, não como repositório de soluções já preparadas. É de Ignacio Rangel a tese do dualismo básico da economia brasileira, o desdobramento das relações de produção, no esquema marxista, em relações internas e relações externas, ou seja, o Brasil voltado para o passado e o Brasil que tenta vislumbrar o futuro. A descoberta do dualismo básico de toda a sociedade subdesenvolvida, onde convive o arcaico com o moderno, o latifúndio com a empresa capitalista de alta tecnologia, o coronelismo com a democracia urbana. Isso não se encontra em nenhum dos autores clássicos e durante muito tempo os economistas, sociólogos e os cientistas políticos tiveram muita dificuldade em ver que a realidade de país subdesenvolvido é esquizofrênica: o que todos nós encontramos, ao lidar com sociedades subdesenvolvidas, é o fato de que não existe uma receita pronta, e de certa forma, todas as soluções preparadas têm que ser adaptadas às diferentes reações do paciente, pois as reações da sociedade arcaica são muito diferentes daquelas da sociedade moderna.

O terceiro exemplo de espírito crítico que eu preparei para citar é de Celso Furtado. Aqui, no meu entender, o que houve foi a adaptação do modelo keynesiano à realidade do subdesenvolvimento. É preciso não esquecer que Celso Furtado teve, certamente, conhecimento do manuscrito do manifesto latino-americano de Raúl Prebisch, de 1949, e esse manifesto já apontava os rumos que deveria seguir a intelectualidade latino-americana. Dizia Prebisch, então: "os jovens economistas latino-americanos devem manter uma independência teórica ao analisarem a realidade do continente e devem sempre denunciar - expressão de Prebisch - o falso senso de universalidade propalado na teoria econômica em vigor nos países desenvolvidos". Isso lembra muito a análise marxista a respeito da noção de interesse geral e de bem comum. Como todos sabem, Marx dizia que não existe interesse geral ou bem comum, porque na verdade isso nada mais é do que a extrapolação do interesse particular específico da classe dominante. De certa forma, nós encontramos sempre isso, no que diz respeito à análise econômica, e hoje mais do que nunca. Francisco de Oliveira mesmo lembrou que a nossa política econômica, política econômica atual, desses executivos de empresas multinacionais, ou de organizações internacionais, esses mesmos que nos governam, nada mais é do que o decalque de manuais 
consagrados nos grandes centros universitários do primeiro mundo. E Celso Furtado mostrou, tomando o impulso keynesiano, mas sabendo distinguir o útil do inútil, que nos países subdesenvolvidos o que há não é excesso de poupança, mas sim escassez de poupança, e com isso ele alterava um dos pressupostos fundamentais da teoria keynesiana. Da mesma sorte, ao tomar de Keynes a noção fundamental de que era preciso conduzir a política econômica sob forma planejada, Celso Furtado mostrou, desde o início, que o objetivo do planejamento estatal era muito diferente daquele pensado por Keynes. Keynes pensava o planejamento no período de entre guerras e após a grande crise de 1929, e portanto o objetivo da programação estatal da atividade econômica era o pleno emprego. Celso Furtado mostrou, de maneira convincente, que era preciso ampliar esse objetivo. O planejamento estatal nada mais é do que a pilotagem do processo de desenvolvimento nacional, e portanto ele extrapola o setor meramente econômico e desdobra o processo de desenvolvimento em três grandes dimensões: a dimensão econômica, a dimensão social, ou seja, a luta contra a desigualdade de condição social e a luta contra esta oposição cultural entre país atrasado e país moderno, e, finalmente, a dimensão política, que nada mais é do que a democracia.

\section{MOMENTO CRÍTICO}

Pois bem, hoje nós nos encontramos num momento crítico, se é o caso de dizer, da vida do gênero humano, e eu estou empregando crítico aí no sentido que Hipócrates deu à palavra. O fundador da medicina, usando desse mesmo verbo kriteô, achava que na evolução da moléstia, de todas as moléstias, havia um momento em que o médico podia fazer o diagnóstico e, por conseguinte, o prognóstico. Antes do momento crítico, era impossível saber exatamente qual era a doença. É nesse momento que o diagnóstico se faz possível e o médico pode saber se haverá cura ou não, na evolução da moléstia.

Nós estamos, penso eu, sem exagero e sem retórica bacharelista, nós estamos nesse momento crítico, e esse momento crítico coincide, no meu modo de entender, com o apogeu do sistema capitalista; apogeu ainda aí no sentido grego, ou seja, é o momento em que o capitalismo se encontra no ponto mais longínquo da terra, provavelmente é a partir daí que ele vai começar o seu ocaso. As grandes crises ainda estão por vir, mas infelizmente neste momento nós não estamos preparados, penso eu, intelec- 
tualmente, para fazer essa análise. Falta-nos esse sentido de radicalidade e de especificidade a que se referiu Chico de Oliveira. É preciso mais do que nunca procurar separar o útil do inútil, o aplicável do inaplicável nas grandes doutrinas sociais e econômicas. É preciso pensar o Brasil não mais como fez a geração de demiurgos, ou seja, pensar o Brasil isolado do mundo. Agora é preciso pensar o Brasil no mundo circunstante. Nós estamos numa fase em que não há nenhuma solução possível para a realidade brasileira, fora do contexto mundial. Não podemos nos deixar levar por um sentido de recusa cega da mundialização. A mundialização é um fato inelutável. $\mathrm{O}$ que deve ser combatido com todas as armas racionais e irracionais, com toda a paixão possível, com a paixão do cérebro e o cérebro da paixão, é sim a globalização capitalista, pois é ela que está nos levando para a catástrofe final. É preciso saber combinar, nesse exame do Brasil no mundo, a defesa dos interesses dos povos subdesenvolvidos com a defesa dos direitos da humanidade, o que parece contraditório mas não é! Não se pode defender um interesse específico de povo subdesenvolvido que vá de encontro ao interesse maior da humanidade. Não é possível, por exemplo, a pretexto de romper com o imperialismo, adotar uma política de desenvolvimento predatório, que destrua as nossas reservas naturais e que não leve em conta - e eu penso evidentemente na Amazônia - o interesse geral da humanidade, aquilo que corresponde a um verdadeiro patrimônio da humanidade que é a manutenção da integridade do meio ambiente. É um desafio enorme, mas, tal como Francisco de Oliveira, penso que se nós tomarmos o método desses redescobridores do Brasil, poderemos chegar a bom resultado. 



\section{O DESAFIO DOS QUE PENSARAM BEM O BRASIL}

CARLOS NELSON COUTINHO

Também queria começar agradecendo o convite para participar dessas bodas de prata do CEDEC, uma instituição que foi e é muito importante para todos nós, mesmo para aqueles que não trabalhamos diretamente no CEDEC. Tive o prazer de ter sido muitas vezes convidado para debates, além de ser um leitor assíduo e um colaborador de Lua Nova, uma das melhores revistas brasileiras. É um prazer para mim estar aqui.

Se Fábio, que foi o segundo, já concordou com Chico, que foi o primeiro, imaginem a minha situação como terceiro, tendo concordado com os dois! Vai ser difícil eu acrescentar algo de novo.

Em primeiro lugar, devo dizer que achei interessante o formato do seminário proposto pelo CEDEC quando distingue entre o "como se pensa" e o "como se deve pensar" o Brasil. Num primeiro momento, essa distinção poderia dar lugar a um equívoco, ou seja, imaginar que o "como se pensa" foi até agora errado e que nós devemos descobrir a partir do nada como pensar doravante. Nas exposições anteriores já ficou muito claro que nós temos uma herança a salvar: nosso país já foi pensado de modo correto, já foi pensado mal em muitos casos, mas já foi também bastante bem pensado em outros. Então, se isso é verdade, não podemos imaginar o "como se deve pensar" sem partir de uma tradição que me parece extremamente valiosa; e, entre esses descobridores que Chico nos lembrou aqui, gostaria de destacar dois autores que me são particularmente caros e me parecem fornecer uma imagem do Brasil extremamente rica e extremamente atual. Poderia dizer que eles, "por acaso", são marxistas, mas não diria assim: diria que são valiosos e atuais precisamente porque são marxistas! Refiro-me, é claro, a Caio Prado Jr. e Florestan Fernandes. Há muitas diferenças entre eles, certamente, algumas significativas, mas chamaria a atenção para um traço que lhes é comum, que é exatamente uma postura radical na busca da especificidade brasileira. De resto, ambos eram 
revolucionários. Acho que Fábio disse muito bem: nem em um nem em outro - mas, talvez, sobretudo em Caio Prado - existem paradigmas prévios para pensar o Brasil. Ambos usam o marxismo como método e não como modelo ou dogma no qual encaixar a nossa realidade.

\section{UMA VIA NÃO CLÁSSICA PARA A MODERNIDADE}

É muito interessante que ambos tenham redescoberto, em suas análises do Brasil, uma problemática presente em dois importantes autores marxistas, Lenin e Gramsci. Ambos descobriram por sua própria conta - já que um não conhecia (Caio Prado) e o outro conhecia mal (Florestan) os conceitos de "via prussiana" de Lenin e o de "revolução passiva" de Gramsci -, a noção de uma via "não clássica" para a modernidade, para o capitalismo. Foi com uma brilhante intuição desta via "não clássica" que ambos pensaram os processos de transição que levaram o Brasil ao capitalismo. O que lhes permitiu não só compreender as desventuras dessa transição, mas também quanto ela foi insuficiente para erradicar da modernidade brasileira os traços mais perversos do nosso passado.

Se relermos hoje um livro como Evolução política do Brasil, publicado em 1933, escrito por um jovem de 26 anos, ficamos impressionados ao ver como toda a análise caiopradiana da Independência tem pontos de analogia evidentes com a análise que Gramsci fez do processo de unificação estatal da Itália, com o Risorgimento, que Gramsci analisa à luz do conceito de "revolução passiva". Ora, Gramsci estava elaborando este conceito, na prisão fascista, no exato momento em que Caio Prado escrevia Evolução política do Brasil. Ambos se deram conta de que há processos de transição que se dão pelo alto, resultam do acordo entre frações das classes dominantes e têm como objetivo principal a exclusão de qualquer protagonismo das camadas subalternas.

Neste tipo de transição, as camadas subalternas manifestam-se através de um "subversivismo esporádico e elementar" (a expressão é de Gramsci), ao passo que as classes dominantes reagem a esses embriões de um movimento que vem de baixo precisamente com manobras pelo alto, que implicam um acordo e uma conciliação entre os segmentos "modernos" e os segmentos "arcaicos" dessas classes. Não se trata, nessas transições, de meras contra-revoluções, mas são precisamente aquilo que Gramsci chamou de "revoluções-restaurações", ou "revoluções passivas", 
que, ao mesmo tempo em que introduzem novidades, conservam muitos elementos da velha ordem. A especificidade deste tipo de transição é precisamente esta: que o novo surge na história marcado por uma profunda conciliação com o velho, com o atraso. Barrington Moore Jr. cunhou para isso um termo preciso: modernização conservadora.

Caio Prado não dispunha de um amplo estoque de categorias marxistas. Ele cita poucas coisas de Lenin, visivelmente ainda não tinha lido $O$ Capital quando escreveu suas principais obras historiográficas, Formação do Brasil contemporâneo e História econômica do Brasil. E, no entanto, foi capaz - o que prova o seu talento — de redescobrir por sua própria conta essa via específica do Brasil para o capitalismo, que é uma via próxima (próxima, evidentemente, mas não igual, precisamente por ser específica) daquilo que Lenin chamou de "via prussiana" e Gramsci, de "revolução passiva".

Lenin elaborou sua noção de via prussiana a partir do modo pelo qual o capitalismo resolveu (ou não resolveu) a questão agrária. É também no exame da questão agrária que Caio Prado concentra sua análise da transição do Brasil para a modernidade. Como é que o Brasil resolveu a questão agrária? Ou melhor, como é que o Brasil não resolveu essa questão? Caio Prado nos mostra que foi exatamente essa "não-resolução", ou seja, o fato de que a introdução do capitalismo no campo se combinou com a permanência do latifúndio e da coerção extra-econômica sobre o trabalhador rural, que gerou toda essa seqüela de desigualdades, esse déficit de cidadania, esse conjunto de injustiças que nos marcam até hoje.

Concordo inteiramente com Chico quando ele diz que o Florestan que elabora uma nova imagem de nosso País é certamente o Florestan de A revolução burguesa no Brasil, sua indiscutível obra-prima. É o marxista Florestan, não o funcionalista que estuda as sociedades tupinambás. Suas outras obras são importantes, muitas são significativas, mas não têm a visão de totalidade, não têm essa dimensão claramente marxista que encontramos em A revolução burguesa no Brasil. Nesta obra, Florestan revela possuir um estoque categorial marxista muito mais rico do que aquele de que dispunha Caio Prado. Florestan põe claramente a questão de uma via "não clássica" para o capitalismo no Brasil. E, enquanto Caio põe a questão agrária no centro de sua análise, Florestan prefere destacar - em sua análise do caminho não clássico do Brasil para a modernidade - a questão da dependência externa, da nossa dependência ao imperialismo. Decerto, também em Caio Prado existe a relação com o imperialismo; e Florestan não subestima a questão agrária. Mas cada um 
deles sublinha um aspecto. Por isso, é importante lê-los em conjunto se quisermos construir ou reconstruir uma imagem marxista do Brasil. Ou seja: se quisermos captar as duas determinações fundamentais de nossa especificidade brasileira, de nossa via não clássica para o capitalismo. Se quisermos compreender as deformações que essa via introduziu em nossa modernidade.

Deve-se recordar que, ao elaborarem suas análises, tanto Caio Prado quanto Florestan se contrapuseram, até com alguma radicalidade, à imagem do Brasil contida nos documentos e na tradição teórica do PCB, do Partido Comunista Brasileiro. Tudo bem para Florestan, que jamais militou no PCB, foi trotsquista em sua juventude e terminou a vida na esquerda do PT. Mas a coisa é bem mais complicada para Caio Prado: ele foi membro do PCB desde 1934-1935, se não estou enganado, e, ao que me consta, morreu sem ter jamais rompido com o Partido. No entanto, quase sempre esteve em polêmica com a direção do PCB, seja na avaliação da aliança com Vargas em 1945, seja no julgamento dos governos JK e Jango, seja na definição da linha política, seja na conceituação da própria realidade brasileira. Todas estas críticas estão sintetizadas em seu último livro significativo, A revolução brasileira, de 1966, um livro que consiste numa devastadora crítica do modelo de pensar o Brasil presente na tradição pecebista. Não me parece ser aqui o momento de tentar entender as razões dessa esquizofrenia. Talvez ela possa ser explicada pela permanente simpatia que Caio Prado manifestou em face da União Soviética, para ele criadora de um "novo mundo" e de uma nova concepção e prática da liberdade.

Mas qual era o modelo pecebista de pensar o Brasil, contra o qual se opuseram tanto Caio quanto Florestan? Era o modelo do Brasil como um país que ainda carecia de uma "revolução democrático-burguesa", ou de "libertação nacional", enquanto condição para atingir a plena modernidade capitalista. Essa foi uma posição que marcou a história do PCB, pelo menos a partir dos anos 30, e que está presente na obra de seus maiores intelectuais, como Nelson Werneck Sodré e Alberto Passos Guimarães. Embora essa posição me pareça hoje essencialmente equivocada, ela não impediu que o PCB desempenhasse uma ação prática essencialmente positiva na história do Brasil. E acho que não digo isso apenas para justificar meus 20 anos de militância nesse partido... Mas, malgrado os acertos práticos, tratava-se de uma matriz teórica que não permitia pensar a especificidade da transição capitalista no Brasil, ou seja, o fato de que o Brasil já era um país capitalista, mas que chegara ao capitalismo através de um tipo específico de revolução burguesa, de uma revolução pelo alto, 
da "via prussiana" (Lenin) ou da "revolução passiva" (Gramsci), ou se preferirmos, através de uma "contra-revolução permanente" que leva a uma "autocracia burguesa" (Florestan).

Portanto, para responder hoje à questão de "como se deve pensar" o Brasil, nós, marxistas, já temos um rico patrimônio de onde partir, não temos de começar da estaca zero. E, como já disse antes, o modo como se deve pensar o Brasil está muito ligado ao modo pelo qual ele já foi pensado. No nosso caso, no caso dos marxistas, trata-se de desenvolver essa rica linha interpretativa elaborada sobretudo por Caio Prado e Florestan e não, absolutamente, de abandoná-la e imaginar que devamos criar uma outra linha inteiramente nova. Mas, dito isso, não devemos esconder que há limites nessa leitura do Brasil, nessa imagem do Brasil presente em Caio Prado e em Florestan. Já vimos que esses processos "não clássicos" de transição para o capitalismo combinam modernização e conservação. É uma forma de transição que reproduz o velho, que repõe o velho sob novas formas, mas que certamente também introduz o novo: não se trata, portanto, de uma simples contra-revolução.

\section{O VELHO E O NOVO}

Ora, tanto na obra de Caio Prado, sobretudo na obra do Caio Prado, mas também na obra do Florestan, há uma tendência a sublinhar os momentos em que o velho permanece no novo e, freqüentemente, em consequiência, a subestimar este novo. Dou um exemplo: num apêndice escrito para A revolução brasileira, em 1977, em pleno governo Geisel, Caio Prado continua insistindo numa tese que está presente em todos os seus artigos da época da Revista Brasiliense, dos anos 50 e início dos 60, ou seja, de que o Brasil não conhecera um efetivo processo de industrialização. Ele fala da industrialização ocorrida a partir dos anos 30 como uma falácia, uma coisa inexistente, que não tem importância na análise do Brasil contemporâneo. Insiste - é uma frase dele, literal quase - que "continuamos o mesmo, mudaram-se as aparências mas não mudou a essência"; ou seja, para ele, o Brasil continuaria um país colonial, exportador de matérias-primas e importador de bens manufaturados.

Pode-se, hoje, até especular: será que Caio Prado não tinha o dom da profecia? Será que ele não viu, antes de todos, que a política neoliberal iniciada com Collor e radicalizada por FHC poderá levar (e 
esperamos que não o faça, que essa política seja interrompida) ao completo desmonte da indústria brasileira, o que certamente ocorrerá se ingressarmos na ALCA? Como não devemos crer em profecias, o fato a registrar é que Caio Prado não viu adequadamente o novo que, em meio à ganga do velho, e malgrado tudo, surgiu do processo de transição pelo alto.

Também em Florestan há uma tendência a sublinhar mais a permanência do velho do que a novidade. Por exemplo, a idéia do Florestan de que vivemos numa contra-revolução prolongada, que gera permanentemente (sob diferentes modalidades) uma forma estatal que ele chama de "autocracia burguesa", parece-me revelar uma incapacidade de compreender adequadamente as virtualidades do novo. Para ele, seríamos condenados permanentemente, enquanto persistir o capitalismo, à autocracia burguesa. Em sua opinião, teria sido autocracia burguesa o período populista, assim como continuou a ser uma forma dissimulada de autocracia burguesa o que ele, com lucidez, chamava de "nova República" entre aspas ou seguida de interrogação. Mas penso, e infelizmente não tenho tempo de argumentar sobre isso, que ele deixou de ver importantes novidades que esses dois momentos (e não só eles) introduziram em nossa realidade. Ou seja: o Brasil se modernizou "pelo alto", prussianamente, passivamente; gerou, com isso, formas extremamente perversas de desigualdade social, tremendos déficits de cidadania, mas o fato é que nosso País se modernizou. E isso nos obriga a novas reflexões e desafios teóricos. Obriga-nos, por exemplo, a entender formas mais sofisticadas de dominação burguesa.

Então, penso que é necessária uma renovação dessa imagem marxista do Brasil (pela qual somos gratos, sobretudo, a Caio e Florestan), uma renovação que nos permita ir além da reflexão já consolidada e absolutamente imprescindível sobre nosso modo peculiar de transição ao capitalismo. Torna-se agora urgente uma reflexão que busque elevar a conceito (como Hegel gostava de dizer) a especificidade do Brasil contemporâneo. É evidente que não posso aqui indicar, nem mesmo superficialmente, os muitos temas que essa nova reflexão exige. Limito-me a propor uma única questão, mas uma questão que me parece muito importante, pelo menos para nós que, além de marxistas, somos também gramscianos. Uma questão que sintetiza muitas outras. Uma questão que nos tem ocupado, a nós gramscianos, não só a mim, mas também, por exemplo, aos amigos Marco Aurélio Nogueira e Luiz Werneck Vianna, aqui presentes. 


\section{BRASIL “ORIENTAL” OU “OCIDENTAL”?}

Formulo esta questão de um modo sumário: o Brasil de hoje é uma sociedade "oriental" ou "ocidental"? Vamos tentar lembrar que sentido têm essas categorias em Gramsci. Gramsci fala sempre de "Oriente" e "Ocidente" pondo os termos entre aspas; com efeito, para ele, não se trata de conceitos geográficos, nem mesmo geopolíticos, mas claramente de conceitos histórico-políticos. Quando fala em "Oriente", ele certamente está pensando sobretudo na Rússia antes da Revolução de 1917; mas, num parágrafo dos Cadernos, também nos diz que, "hoje", no momento em que escrevia, ou seja, no início dos anos 30, "Oriente" seriam apenas os países que (com a terminologia da Terceira Internacional) ele chama de "coloniais e semicoloniais".

E como Gramsci define "Oriente"? Ele diz assim (e é literal essa minha citação): "No Oriente, o Estado é tudo e a sociedade civil é primitiva e gelatinosa". E o que é para ele "Ocidente"? Neste caso, ele diz que se trata de uma condição na qual há "un giusto rapporto", ou seja, uma relação equilibrada entre Estado e sociedade civil. Para Gramsci, de resto, o Estado (que ele chama também de "Estato stricto sensu", "Estadocoerção", "sociedade política") e a "sociedade civil" são momentos do Estado "ampliado", isto é, são duas esferas que fazem parte de uma mesma totalidade social. Entre eles existe uma unidade na diversidade. Além disso, para um bom leitor da obra de Gramsci, é fácil perceber que ele não entende a contraposição "Oriente"/“Ocidente" apenas como uma contraposição sincrônica, mas também, e talvez sobretudo, diacrônica: ou seja, países que eram "orientais" podem sofrer processos de "ocidentalização". Podemos ver claramente que, quando descreve a Europa do início do século XIX, bem como os movimentos revolucionários que ela conhece ao longo desse século, Gramsci busca nos mostrar um processo de "ocidentalização" das sociedades européias, no sentido de que cada vez mais se socializa a política, de que se criam movimentos de massa a partir de baixo, partidos políticos de massa e sindicatos, de que se conquista o sufrágio universal. Todo esse processo de socialização da política leva à criação, precisamente, desses "aparelhos privados de hegemonia", que Gramsci chamou de sociedade civil.

Volto, então, à minha questão, uma questão decisiva se quisermos refletir sobre a especificidade do Brasil de hoje, desse Brasil que resulta de transformações pelo alto, de revoluções passivas etc.: somos uma sociedade "ocidental" ou "oriental"? Certamente o Brasil foi um país de 
tipo "oriental" durante um largo período da sua história. Talvez nunca um "Oriente" tão radicalmente "Oriente" quanto foi a Rússia czarista, já que, mesmo ao longo do período imperial, tínhamos um Parlamento, ainda que fosse pequena sua influência; tínhamos uma Constituição, ainda que autoritária e frequientemente desrespeitada, o que nunca existiu na Rússia czarista. Mas certamente a sociedade civil, durante toda a época imperial e durante boa parte da Primeira República, era primitiva e gelatinosa. Nesse sentido, penso que a caracterização de "oriental" é correta para o Brasil, pelo menos até 1930 .

É verdade que embriões de sociedade civil se manifestam na República Velha. Um deles, muito expressivo - relembrado aqui por Fábio - foi a fundação em 1922 do PCB, o primeiro partido surgido no Brasil fora do aparelho de Estado, ou seja, a partir de baixo. Sem dúvida, na época, era um partido pequeno, tinha pouca influência social, mas era o embrião de alguma coisa que tinha a intenção de ser um partido de massa. Surge ao mesmo tempo, nesse período, um movimento sindical expressivo, certamente ainda recrutando partes muito exíguas da população brasileira, mas que tem um peso, que promove duas ou três greves gerais significativas. Surge também, ainda na "República Velha", uma imprensa operária, ou seja, uma organização da cultura que é elemento importante de uma autêntica sociedade civil. Portanto, há embriões de sociedade civil, mas certamente não suficientemente desenvolvidos a ponto de impedir que a transformação feita em 1930 seja a mais emblemática manifestação de uma revolução passiva no Brasil. A chamada "Revolução de 30" teve até um seu "teórico", o Antonio Carlos mineiro. Ele não hesitou em formular, pouco antes do movimento, a seguinte recomendação: "Façamos a revolução antes que o povo a faça". Parecido com isso só a frase que o personagem aristocrata de Lampedusa, durante o Risorgimento italiano, diz ao seu sobrinho arrivista: "É preciso que tudo mude para que permaneça como está".

Mas o Brasil pós-30, malgrado o modo prussiano da transformação, dizia eu, revelou que a sociedade civil brasileira já tinha se desenvolvido razoavelmente. No início dos anos 30, temos no Brasil, pela primeira vez, a existência de dois partidos políticos de massa de nível nacional, ou seja, a Aliança Nacional Libertadora, que é um organismo de massa liderado pelo Partido Comunista, mas que transcende as fronteiras do Partido Comunista, e a Ação Integralista Brasileira, o partido fascista, que também teve uma dimensão de massa. Mas essa ativação da sociedade civil não era uma coisa sólida, tanto que tivemos em 1937 um golpe militar-civil pelo alto, 
que ignorou qualquer recurso a massas organizadas (diferente nisso, portanto, do fascismo e do nazismo). Ou seja: um golpe típico de país "oriental".

Ao longo do chamado período populista, seguramente a sociedade civil se desenvolve. Creio até que, no fim do período, essa sociedade civil ganha uma dimensão extremamente significativa, um grau bastante razoável de autonomia em relação ao Estado. Há uma evidente socialização da política entre nós. Nessa medida, penso que uma das explicações do golpe de 64 é exatamente esta: ele foi o modo de uma burguesia unificada pelo medo de quebrar esse protagonismo crescente que a sociedade civil apresentava, inclusive trazendo por exemplo, naquela época, um novo e importante ator político que era o movimento dos trabalhadores rurais, tanto nos sindicatos rurais quanto nas ligas camponesas, claros precursores do MST.

É uma coisa paradoxal, mas eu diria que a evidência de que o Brasil se "ocidentalizou", ou seja, de que tem hoje "un giusto rapporto" entre sociedade civil e Estado, se manifesta paradoxalmente no final do período ditatorial e, bem mais ainda, no período de transição. Há um artigo muito interessante de Wanderley Guilherme dos Santos, que infelizmente não pôde comparecer ao nosso debate de hoje, que se chama "A 'pós-revolução' brasileira". Nele, Wanderley nos mostra uma série de dados que indicam o forte associativismo que marca o final dos anos $70 \mathrm{e}$ o início dos anos 80 no Brasil. Um associativismo que envolve associação de moradores, de favelados, o sindicalismo urbano e sobretudo rural. $\mathrm{Ou}$ seja: mostra-nos um processo de ativação da sociedade civil muito expressivo, que eu diria, inclusive, que está na raiz dos processos de desagregação da ditadura e de sua derrota final.

Alguém perguntaria: "Mas não é um paradoxo que uma sociedade civil cresça sob uma ditadura?" E eu responderia: cresceu malgrado a ditadura. A ditadura brasileira não foi uma ditadura fascista; foi uma ditadura modernizadora, que se empenhou em desenvolver o capitalismo no Brasil, em modernizá-lo. Ela foi, para lembrar o título de um belo livro do querido mestre e amigo Octavio Ianni, aqui presente, A ditadura do grande capital. Não foi uma ditadura do latifúndio contra a indústria, não foi a expressão do atraso contra o progresso, mas foi uma ditadura que modernizou as forças produtivas. Mas não foi uma ditadura fascista no sentido de que não organizou uma base de massa, que não absorveu a sociedade civil num Estado do tipo totalitário. Foi obrigada a conviver contraditoriamente com uma sociedade civil que ela mesma (ao desenvolver o capitalismo) estimulava, tentou reprimi-la quando e quanto pode, tentou 
cooptá-la freqüentemente, mas não pôde impedir que ela se desenvolvesse, ganhasse uma dinâmica própria e terminasse por ser um dos fatores decisivos da corrosão do sistema ditatorial, do seu declínio histórico (uma expressão que meu amigo Armênio Guedes gostava de usar na época) e, finalmente, de sua derrota.

\section{“OCIDENTE PERIFÉRICO”}

Então, emergimos da ditadura como uma sociedade "ocidental". Vejam bem: gostaria de deixar muito claro que, ao dizer isso, não estou imaginando que o Brasil chegou ao Primeiro Mundo. Nos Cadernos do cárcere, Gramsci fala em "Ocidente periférico" e inclui nesse tipo de "Ocidente" a Itália, a Espanha, a Grécia, acho que também Portugal. Diria então: o Brasil é um claro exemplo de "Ocidente" periférico, como a Argentina, o Chile, o México, o Uruguai. E "periférico" em vários sentidos. Primeiro deles: porque somos periferia do capitalismo e sempre estivemos envolvidos no movimento internacional do capital (agora talvez ainda mais) numa posição indiscutivelmente subalterna. Segundo: porque somos um "Ocidente" atravessado de "Orientes". Quem conhece a Bahia e eu a conheço muito bem porque lá nasci, lá tenho família, amigos, raízes e saudades - sabe que a Bahia tem muito de "Oriente". Antonio Carlos Magalhães e seus asseclas controlam o aparelho de Estado (Executivo, Legislativo e Judiciário) e o pouco que há de sociedade civil de uma maneira que dista muito daquele "justo equilíbrio" que caracteriza uma situação "ocidental". O que ocorre na Bahia provavelmente se repete nos outros estados do Nordeste e do Norte.

Mas mesmo ACM - e eu gostaria de sublinhar isso - não é um simples representante do atraso, não é um representante do latifúndio: ele é um representante do grande capital na Bahia, dos grandes grupos capitalistas nacionais e internacionais. Então, até ACM tem seu lado "ocidental". E acho que essa coexistência de oriente/ocidente, que é uma especificidade do "Ocidente periférico", foi muito bem explicada em dado momento, no terreno econômico, pelo nosso querido Chico de Oliveira, aqui presente, em seu belíssimo ensaio Crítica da razão dualista, certamente uma das obras-primas de nossa ensaística. O que Chico nos mostra? Que o "Ocidente" brasileiro se alimenta e necessita do "Oriente" para funcionar e para se reproduzir, para se desenvolver. Portanto, não há dualismo. Chico nos mostra neste ensaio, como de resto Gramsci já o havia mostrado em seus belos estudos sobre a 
"questão meridional" italiana, que o atraso de uma parte do país (o seu "Oriente") é funcional ao progresso de outra (o seu "Ocidente").

"Ocidente periférico", sim, marcado pelas taras de transformações pelo alto, claramente antipopulares, excludentes. Mas, malgrado tudo, "Ocidente". Isso tem indiscutíveis implicações não só no modo de "como pensar" o Brasil, mas sobretudo de como agir para transformá-lo. Lembrem-se de que Gramsci faz essa distinção não só para definir diferentes tipos de Estado, mas, sobretudo, para definir diferentes tipos de estratégia revolucionária. Se efetivamente somos "Ocidente", ainda que periférico, temos de assumir a estratégia proposta por Gramsci para esse tipo de sociedade, ou seja, a guerra de posição, que implica uma longa batalha pela conquista do que Gramsci chamou de "hegemonia civil", batalha que implica uma conquista progressiva de espaços e de posições que nos levem, finalmente, a inverter a correlação de forças e alterar a natureza do Estado e, a partir daí, modificar também a estrutura social. Portanto, não se trata de optar pela reforma contra a revolução: trata-se de fazer das reformas o meio privilegiado de um novo tipo de revolução.

Lembro-me que Palmiro Togliatti, o notável dirigente comunista italiano, dizia o seguinte: "Quem erra na análise erra na política". Então me parece muito importante que tenhamos uma correta imagem do Brasil para que nos seja possível, a partir dessa imagem, elaborar uma estratégia política adequada às condições desse Brasil moderno, que é o Brasil em que vivemos, embora essa modernidade tenha sido gerada pelas vias transversas do prussianismo, das revoluções passivas, das "autocracias burguesas" Se queremos saber "como pensar" o Brasil, eu não hesitaria em dizer, em breves palavras: devemos pensá-lo na perspectiva da transformação radical, de uma revolução socialista. 



\title{
ARTICULAR TRANSFORMAÇÃO E CONSERVAÇÃO
}

\author{
Marco Aurélio Garcia
}

O tipo de discussão que estamos tendo aqui coloca uma das questões centrais do pensar o Brasil e que apareceu aqui sobre vários registros, todos eles apontando para o mesmo fenômeno. Chamemo-lo de uma tendência a articular a transformação com a conservação. Eu veria dois problemas para discussão. Primeiro, sem negar que isso se constitua numa especificidade brasileira, gostaria de pensar essa a especificidade um pouco além do que habitualmente é pensada, para evitar o truísmo de dizer que todos os casos nacionais são específicos. Quero questionar a tese de que essa tendência da transição por cima seja uma especificidade tão pronunciadamente brasileira, ou da via prussiana, ou daquilo que foi contabilizado de maneira geral como revolução passiva. Porque é possível que alguns desses conceitos, que são muito ricos e que nos permitem pensar mediações históricas, sejam às vezes tributários de uma certa visão linear de história. Fiquei muito sensibilizado para esse tipo de questão ao ler o livro de Arno Mayer, A força da tradição, no qual ele se propõe algo interessante, que é fazer uma espécie de história da Europa do século 19 mediante uma "interpretação marxista de cima para baixo". Nisso ele privilegia concretamente a "simbiose ativa" entre a burguesia e o antigo regime. Diz ele que essa simbiose ativa faz com que o antigo regime não apareça no século 19 até 1914, e mesmo depois de 14, exclusivamente como uma espécie de sobrevivência, mas que ele produz sobre a burguesia um processo de cooptação e transformação. A burguesia pensada como uma classe, a burguesia emergente, carente de valores, uma burguesia "protonacional", como ele diz. E ele vai ancorar essa análise toda numa exuberante demonstração de dados sobre a economia, sobre a sociedade, sobre a política, sobre a cultura. Quando li isso - e é um modelo que ele aplica com diversidade, na França menos, na Rússia obviamente mais, na Alemanha bastante, na Inglaterra um pouco menos, mas enfim, em todos esses países teria havido esse processo - eu fiquei pensan- 
do um pouco nas vicissitudes históricas que o nosso país enfrentou. Em que medida, efetivamente, essa transformação/conservação não é tanto um dualismo quanto algo tão articulado que se transforma quase que em algo congênito ao nosso processo histórico. Isso, a meu juízo, relativiza alguns conceitos - como os enunciados por Carlos Nelson, de oriente/ocidente, a de sociedades gelatinosas - que têm força descritiva, mas que perdem um pouco da sua consistência. Pensando não como cientista social e político, que não sou, mas como historiador, em alguns casos essas interpretações são tributárias de uma avaliação historiográfica equivocada, por sua vez também determinada por uma certa concepção evolucionista da história.

Não sei se podemos atribuir um caráter tão gelatinoso à sociedade russa, que no espaço de 12 anos realizou três movimentos sociais absolutamente extraordinários, dos quais saiu, inclusive, uma grande transformação no século 20. Será que ela não é gelatinosa do ponto de vista dos conceitos ocidentais? E por outro lado, sociedades bem pouco gelatinosas foram muito mais submetidas a esse processo de transformação/conservação. Pensemos o que foi a Inglaterra do século 19, ou mesmo do século 18, sem com isso que eu esteja aqui desqualificando concretamente os processos de transformação social que ocorreram nesse país; porque é evidente que nos processos de democratização pelos quais esses países passaram estão fortemente as marcas das classes trabalhadoras, inclusive as marcas que surgem nas derrotas.

É necessário pensar a estrutura de classe no Brasil, as mudanças brutais pelas quais a sociedade brasileira está passando. Quando vejo a análises antigas da sociedade brasileira eu muitas vezes me pergunto se nós não estamos pensando o Brasil com uma grade conceitual inadequada. Digo isso porque em todas as intervenções houve uma saudável invocação dos momentos nos quais os intelectuais se debruçaram sobre o país. Enfatizou-se muito os anos 30, mas eu lembraria que na transição da sociedade imperial escravocrata para a transição do Brasil republicano, quando também havia questões importantes em jogo, nós tivemos grandes intelectuais. Um deles foi citado aqui, Euclydes da Cunha, e outro, que era um homem conservador mas que produziu num determinado momento um pensamento extremamente relevante sobre o problema da desigualdade no Brasil, que é Joaquim Nabuco no seu livro sobre o abolicionismo. Depois nós temos os anos 30 e temos um outro período sobre o qual pouco se falou e que me parece relevante. Trata-se do período que antecede o golpe de Estado, os anos 50 e anos 60 , onde de uma certa maneira o modelo de desenvolvimento encontrou seus limites e muitos intelectuais tentaram pensá-lo: Celso Furtado, Raymundo Faoro (talvez porque fosse um marginal naquele momento) e, sem dúvida 
nenhuma, o ISEB, com todo os seus problemas, e a escola sociológica de São Paulo, está aqui o Octávio Ianni como um exemplo claro de uma reflexão que se fez sobre os limites que o capitalismo brasileiro enfrentava naquele momento e sobre as alternativas que se abriam. Eu não estou muito preocupado nas respostas que foram dadas, algumas até hoje têm enorme pertinência. Estou mais interessado em saber as perguntas que foram colocadas, e essas de uma maneira geral tinham uma importância muito grande.

Qual é o drama que nós vivemos? Em todos esses momentos a que aludi havia movimentos sociais importantes, esse pensamento ele não se deu no vazio. O dado novo é que a partir do final dos anos 70 , nos 80 e nos 90 nós tivemos uma mobilização sem precedentes da sociedade brasileira, houve um gigantesco movimento social, composto de uma miríade de movimentos sociais visíveis, invisíveis, e que colocavam concretamente em questão o modelo que se esgotara no final dos 70 e no começo dos 80 . Mas, a meu juízo, o pensamento não acompanhou o movimento social. A despeito de obras importantes não se produziu uma reflexão à altura, não houve um movimento com a força comparável a outros momentos da nossa história.

Isso a meu juízo é interessante de examinar, conjuntamente com essa reflexão sobre o pensamento. Não há pensamento importante se ele não reflete a realidade, e se ele não reflete também sobre os outros pensamentos que foram feitos sobre a realidade. Ele tem que realizar esse duplo movimento, de reflexão sobre a realidade e de reflexão crítica sobre seus antecedentes. Se nós vamos realizar isso, valeria a pena tentar recuperar a agenda do pensamento brasileiro. Eu chegaria a uma conclusão interessante: comparado com os momentos luminares do pensamento social brasileiro no passado, talvez nunca as três grandes questões da agenda, tenham sido colocadas de forma tão equilibrada como hoje estão. Essas três questões viajam junto com a evolução do capitalismo, e apareceram pela primeira vez na história com uma força enorme em 1848, na Europa: a questão social, que correspondia justamente ao impacto que o capitalismo produzia na destruição da sociedade tradicional, na organização da sociedade de classes, no surgimento de uma burguesia, de um proletariado; a questão democrática, na medida em que a Revolução Francesa havia produzido paradigmas que a Restauração não tinha conseguido destruir mas tinha conseguido inibir nem o liberalismo conseguia atualizar; e a questão nacional, que para alguns países não era uma questão fundamental mas para outros, por exemplo para a Itália e para a Alemanha, era essencial. E a questão nacional é não só o problema do lugar de um país no mundo, mas é também a forma pela qual esse país se constitui, o tema da federação. $\mathrm{Na}$ 
Alemanha e na Itália era isso, Alemanha menos pois não havia o problema da dominação externa que havia na Itália, mas em ambas havia o problema da constituição de um Estado, da natureza que teria esse Estado do ponto de vista da articulação das partes que o iriam compor.

Essas questões elas estão, de certa maneira, presentes na nossa discussão. A questão social está presente por que? Porque ela vinha se arrastando, ela foi de uma certa maneira subsumida no período desenvolvimentista, e ela depois apareceu no facilitário neo-liberal como solúvel pelo mercado, mas agravou-se. Hoje ele aponta, concretamente, para um tema que não pode ser desconsiderado, que é o do modelo econômico. A última vertente neoliberal consiste exatamente em dizer que não, o modelo é esse mesmo e o social será resolvido através do compensatório, das medidas de políticas compensatórias. É claro que medidas compensatórias devem ser adotadas para enfrentar emergências. Mas como se compatibiliza efetivamente um modelo que, de modo diferente ao neoliberal ou do nacionaldesenvolvimentista, coloca concretamente o crescimento com distribuição? Um velho tema, sobre o qual se escreveu muito e se resolveu pouco.

Em segundo lugar, sustento que tivemos um avanço maior do que nunca no tema democrático. Não é de se subestimar o fato de que o Brasil vive há 17 anos com sistema de eleições, digamos que isso não é condição suficiente mas é uma condição necessária e não desprezível. Ao mesmo tempo, neste período, foram suscitados outros temas importantes. A questão dos direitos humanos, por exemplo, nunca teve a relevância que passou a ter hoje. A noção mesmo de cidadania, que todos aqueles que tinham formação marxista deixavam, de uma certa forma, nas mãos do liberalismo, foi resubstantivada nos debates atuais. Os temas sociais e os temas democráticos, ainda que sem necessariamente apontar para um novo modelo econômico, ganharam uma importância extremamente forte nos anos 80 e nos anos 90 .

O grande problema é que o neoliberalismo foi tardio no Brasil e foi tardio porque a sociedade resistiu, não porque chegou tarde. Ele ficou à porta esperando concretamente e foi uma derrota do embate de classes que permitiu, efetivamente, a sua implementação. Isso fez com que a discussão sobre a questão nacional fosse postergada, especialmente no que diz respeito à questão nacional entendida como lugar do Brasil no mundo.

A questão é: estaremos num novo momento de pensar o Brasil? Os demiurgos estarão de volta, e que desafios que se colocam para eles? Evidentemente não sucumbirei ao facilitário dizendo que os demiurgos até agora pensaram o Brasil, trata-se de transformá-lo. 


\section{PENSAR DE OUTRO MODO UM OUTRO BRASIL}

OCTÁVIO IANNI

Queria fazer uma breve observação sobre o seguinte. Gostei muito do debate, inclusive da colocação que o Marco Aurélio está fazendo agora. Avançamos bastante na reflexão sobre o tema, mas qual é o tema? Pensar o Brasil, como pensar o Brasil, como se pensa o Brasil e o que pensar sobre o Brasil. Acho que há uma contribuição importante no que nós estamos fazendo, mas sinto que está faltando algo. Será que o que está acontecendo nesses dias, nestes anos, nesta época chamada de transição não é algo que é extremamente provocativo e desafiador em termos de tudo o que se pensou? Será que nós podemos falar nesses clássicos como autores que ainda são importantes para pensar o contemporâneo? Ou será que eles estão referidos a um Brasil que não existe mais? Eu gosto da hipótese de que o Brasil de que eles falam não existe mais. E olha que gosto de história! Acho que a história é fundamental, fiz e faço muita pesquisa histórica, mas acho que aquele Brasil não existe mais e estou inclinado a sentir que o Brasil de Celso Furtado, de Florestan Fernandes, de Faoro, de Antonio Candido, para mencionar uma geração que pensou novamente o Brasil nos quadros que eu chamaria de projeto nacional, de uma proposta que foi muito forte numa certa época, esse Brasil também talvez já não exista mais!

Vale a pena imaginar que estamos nos perguntando como pensar o Brasil hoje, não somente para resgatar o que se pensou, mas para tentar nos colocar diante da questão: afinal que Brasil é esse? Será que é o mesmo? Por que não admitirmos a hipótese de que não é mais, que aquele Brasil não existe mais? Claro, existe o território, existe o povo, existe até a língua, até a bandeira, existe muita coisa que tem a ver, mas a mudança pode ter sido excessivamente profunda. Houve numa certa época um vigoroso projeto nacional em desenvolvimento que chegou a realizar amplamente, em termos de economia, de política, de cultura, a universidade etc., 
uma série de criações. Eu diria mesmo que a obra de Faoro, a obra de Candido, de Florestan, de Caio Prado, de Celso Furtado e de vários outros, inclusive alguns que estão aqui, são obras enraizadas no projeto nacional não no projeto nacional dos meus sonhos ou de vários de nós, mas num projeto de capitalismo nacional. Celso Furtado insistiu muito na idéia de que o Brasil tinha conseguido interiorizar os mecanismos decisórios. $\mathrm{Na}$ apresentação do Plano Trienal ele diz que o Brasil já alcançou todas as condições para um desenvolvimento auto-sustentado. Agora esse Brasil desabou, está desmontado.

Tenho a impressão de que as perguntas que o CEDEC nos faz têm a ver com o fato de que não sabemos onde estamos. Queremos nos agarrar aos clássicos, queremos nos agarrar a vários autores importantes e a várias experiências notáveis, mas tenho a sensação de que nós estamos em face de uma conjuntura, ou de uma época, de um novo ciclo, em que o Brasil do qual nós queremos falar ou o Brasil sobre o qual queremos pensar é um Brasil que não é mais nem o Brasil do projeto nacional e muito menos o Brasil anterior. O que nós notamos no âmbito do intelectual, da academia, inclusive de elites políticas e algumas outras, é que há uma inquietação, há uma dificuldade para reconhecer que o Brasil mudou profundamente. Se não há mais o projeto nacional, se ele foi totalmente desmontado, este Brasil de que pensamos, sobre o qual pensamos ou sobre o qual queremos refletir é não mais não menos do que, fundamentalmente, uma província do capitalismo mundial. Os governantes são funcionários, não são governantes; eles seguem diretrizes que estão estabelecidas nas corporações e em outras organizações. A maneira pela qual o país está sendo gestado é muito sintomática de que o que está em causa não é soberania, não é um projeto nacional, é fundamentalmente gestionar uma província do capitalismo mundial. 


\section{DEBATES}

MILTON LAHUERTA - Os expositores falaram bastante dos intelectuais demiurgos. Procuraram ressaltar como nesses intelectuais havia um compromisso acentuado com a idéia de um projeto para o país. Exatamente por essa forma de entrar no tema, fica a pergunta: e o tema da mesa, "como pensar"? Ficou sugerida pelos três expositores uma aposta em como pensar: pensar com radicalidade, pensar "gramscianamente", pensar com paixão. Mas não nos deram pistas de como fazer isso.

O que me fica dessa exposição e até de alguns dos debates que foram travados é que esses autores, mais do que datados, são derrotados. Do ponto de vista das suas consequiências o seu pensamento não se realizou, não se cumpriu. Outros pensamentos foram vitoriosos, e interessa exatamente refletir sobre qual pensamento foi vitorioso. O que é hoje hegemônico politicamente, ou pelo menos comanda politicamente esse país? É o resultado também de um confronto de interpretações, de uma interpretação que se fez vitoriosa, uma interpretação que se gestou inclusive nesta casa. Houve nesta uma vertente que se realizou como política, realizou-se mesmo de modo tão radical que foi capaz de se desdobrar em duas propostas políticas, a do PT e a do PSDB. É claro que em ambas há outros elementos, outros componentes, mas, assim como a do PT tem muito a ver com a formulação de Weffort, por exemplo, quando ele anunciava, no início dos anos 70, um horizonte de ruptura com a tradição identificada como populista, no caso do PSDB, tem a ver também com as posições que Fernando Henrique defendia já desde o final dos anos 60, quando dizia que no contexto da dependência estrutural não é possível pensar em política hegemônica, somente em reações adaptativas. Hoje temos uma atitude de reações adaptativas, e isso está muito bem articulado com uma determinada leitura que se fez a partir desta escola, que recusava fundamentalmente o nacional desenvolvimentismo, identificando-o fundamentalmente - na teoria do populismo isso foi levado às últimas conseqüências - a uma política de manipulação de massas. 
Diante disso, como podemos pensar o futuro, e como podemos fazer a crítica do que está acontecendo hoje se não fizermos também o acerto de contas com essas interpretações vitoriosas? Porque as aqui evocadas não foram vitoriosas.

Além dessa questão geral eu gostaria de fazer uma questão especifica para Carlos Nelson Coutinho, que diz respeito à sua leitura de Gramsci. É uma leitura com um viés, o de pensar a história em termos de que ela não foi o que deveria ter sido, de um processo que não teve as rupturas que poderia e deveria ter tido. Sinto falta neste ponto do Gramsci que pensa a revolução passiva, não mais com algo que representa um déficit de mudança ou de ruptura, mas num outro nível: como um critério de interpretação de toda uma época. É isto que vai propiciar a idéia de americanismo, que lhe permitiria nos anos 30, quando o grande modelo de referência era a experiência socialista no mundo soviético, observar a experiência americana e afirmar que ela, sim, tinha capacidade de universalização. Isso anuncia um horizonte de mudança possível no contexto do capitalismo: mudanças que se dariam não vai mais por rupturas mas por transformações moleculares. Isso nos põe no cerne de um problema muito sério, quando o americanismo transcende as fronteiras dos Estados Unidos e se torna um modo de vida praticamente planetário. Não seria interessante retomar esse Gramsci para pensar, a partir do Brasil, estes problemas que vão muito além do Brasil, que dizem respeito ao americanismo que vivemos hoje?

$* * *$

ALBERTO AGGIO - Vou retomar o conceito de revolução passiva, que esteve presente nas últimas intervenções. Se considerarmos o que propôs há pouco Octavio Ianni, se podemos admitir que o Brasil mudou de maneira extraordinariamente profunda, então eu perguntaria se o conceito de revolução passiva, na sua formulação final por Gramsci, não tem bastante utilidade para nós, hoje. Isso iria contra a observação de Marco Aurélio Garcia, de que conceitos como esse poderiam ser úteis de um ponto de vista histórico, mas pouco úteis para se pensar a circunstância presente, e portanto a estratégia dos atores. Ela permitiria compreender a circunstância, já lembrada aqui por Werneck, de que em certa medida o PT e o PSDB têm as suas origens intelectuais neste mesmo lugar, que é a Universidade de São Paulo. Sendo assim, também é possível pensar que esse contexto dos últimos anos pode evidenciar um tipo de cooptação de atores intelectuais. Afinal, o transformismo também é uma dimensão dessa mesma idéia da revolução passiva. 
CARLOS NELSON COUTINHO - Um mundo de questões! Vou me fixar em algumas. Primeiro, na intervenção de Marco Aurélio Garcia, na qual pareceu-me ver uma crítica ao uso das noções de "Oriente" e "Ocidente", que poderiam levar a um evolucionismo. Em primeiro lugar, creio que a justa crítica ao evolucionismo entendido como um finalismo teleológico não nos deve levar ao abandono da idéia de uma historicidade dos processos. Ou seja: há etapas históricas diferenciadas, portanto há uma evolução. Não conheço um caso, mas é mesmo possível que exista, ou que venha a existir, um processo de "orientalização", ou seja, de passagem de uma estrutura de tipo ocidental para uma de tipo oriental. Isso seria uma regressão, pois os processos históricos até agora evidenciados indicam que a ocidentalização é posterior à orientalização.

Concordo com sua observação de que a enorme ativação dos movimentos sociais no Brasil, ocorrida no final dos anos 70 e início dos anos 80, não se expressou, teoricamente, de uma maneira tão rica quanto nos anos 30. Isso demandaria análises mais finas, porém, em princípio, estou de acordo. E você observou muito bem, falando dos anos 60 , que o que se pensou naquele período histórico não foi pouca coisa. Você identificou alguns sujeitos desse pensamento. Por exemplo, quem de nós, jovens na época, não lia aqueles livrinhos do ISEB de ponta a ponta? O ISEB tem um peso decisivo na formação de nós todos que não estudamos na USP, porque acho que quem estudou na USP teve uma outra formação. Eu só conheci o chamado "pensamento uspiano" depois do golpe de 64, quando vim para o Rio. Até então eu era um leitor de Caio Prado Jr., de Nelson Werneck Sodré e do ISEB; aliás, ler Nelson Werneck Sodré e o ISEB era mais ou menos a mesma coisa. Acho importante destacar esse fato. Como acho importante lembrar que nenhum de nós, que vivíamos fora de São Paulo, tivemos a menor idéia de que aqui se fazia um seminário sobre $O$ Capital. Acho que os participantes deste seminário valorizam excessivamente o que fizeram. Eu, na Bahia, e Leandro Konder, no Rio, já líamos não só Marx, mas também Gramsci, Lukács, Benjamin.

Entendo a intervenção de Octávio Ianni como um desafio, para nos obrigar a pensar o que é que mudou neste país, em que mudou, que categorias se tornaram anacrônicas. Penso que os demiurgos os demiurgos do Brasil citados por Francisco de Oliveira ainda têm coisas a nos dizer. São "demiurgos", são "clássicos", porque ainda falam de determinações que continuam presentes na totalidade social do Brasil de hoje. Se não 
fosse assim, por que seriam “clássicos”? Será que Octavio acha que seus livros dos anos 60 e 70 deixaram de ser atuais? Não é minha opinião.

Estamos assistindo nos últimos anos no Brasil precisamente o desmonte de um projeto nacional que começa em 30, com Vargas, e atravessa toda a ditadura. Temos um período de continuidade no qual os militares não foram infiéis a esse projeto nacional, mantiveram o tipo de Estado que foi criado por Vargas, mais ou menos a mesma política econômica, empenharam-se para solidificar um capitalismo que, evidentemente, era aberto ao capital internacional (aliás, já o era desde o tempo de Vargas e sobretudo de JK). Mas os militares, malgrado tudo (e não é pouco!), tinham um projeto de nação. Claro, tratava-se de uma nação excludente, de uma nação autoritária, fundada no privilégio de algumas elites, na repressão aos de baixo, mas havia por trás de tudo uma idéia de nação. De Getúlio a Geisel existiu uma idéia de nação. Hoje temos a completa desconstrução do projeto nacional.

Octávio Ianni propõe uma importante questão: tem sentido retomar um projeto nacional no Brasil de hoje? Eu diria que, nos moldes do longo ciclo Vargas-Geisel, certamente não. Mas creio que, apesar da dita globalização, ainda temos que repensar um projeto de nação. A nação ainda é uma arena, creio que privilegiada, da luta de classes. O Estado nacional ainda é um sujeito de soberania importante no mundo de hoje. Mas o que seria hoje um projeto nacional? Um projeto que inclua e não exclua, que democratize fundamentalmente as estruturas sociais, que certamente leve em conta que para todas as nações é inevitável hoje a relação com a economia globalizada. Mas, sobretudo, que pense essa relação a partir dos nossos interesses não só como classe, mas também como nação. Que, por exemplo, recuse liminarmente uma coisa como a ALCA. Que tenha uma política industrial voltada para o mercado interno. Deve haver, no mundo globalizado, lugar para um país que tenha um projeto nacional. Porque, se desistirmos disso, seremos colônia mesmo. A questão é: esse projeto de nação ainda pode ser hegemonizado pelas classes dominantes, pela burguesia brasileira? Dificilmente. Um verdadeiro projeto de nação, hoje, só será exeqüível se existir uma hegemonia política do mundo do trabalho.

Vamos à questão de Milton Lahuerta e Alberto Aggio sobre a revolução passiva em Gramsci e o Brasil. Tentemos primeiro discutir a questão filologicamente, ou seja, tentar lembrar o que Gramsci efetivamente disse sobre isso em seu texto, na letra do seu texto. Claro, os Cadernos gramscianos são um work in progress. É fácil ver, numa edição crítica em que os textos estejam dispostos cronologicamente, que Gramsci 
vai elaborando progressivamente seus conceitos, vai burilando-os ao longo dos seis anos em que efetivamente trabalhou nos Cadernos.

Este é o caso, entre muitos outros, do conceito de "revolução passiva". Gramsci encontrou essa expressão num historiador italiano do século XIX, Vincenzo Cuoco, que escreveu um livro sobre a revolução napolitana de 1799. Imediatamente ele viu nessa expressão, que transformou em conceito, um bom "gancho" para pensar um processo específico, o da unificação estatal italiana, o Risorgimento. No Risorgimento, Gramsci viu transformismo, cooptação, acordo pelo alto, exclusão das massas populares, ditadura sem hegemonia, e assim por diante. Para ele, todo o Risorgimento foi "revolução passiva".

Progressivamente, contudo, ele ampliou esse conceito, levando-o a abranger inteiras épocas históricas, duas em particular. Há o período da Restauração na Europa, ocorrido depois da derrota definitiva de Napoleão e da formação da Santa Aliança, de 1815 até 1871. Nesse período, para o qual é muito válida a expressão gramsciana "revolução-restauração", as classes dominantes incorporaram algumas demandas colocadas pela Revolução Francesa, mas dentro de limites e com exclusão das massas populares. Portanto, revolução passiva como resposta à Revolução Francesa. Outra época histórica começa com a Revolução Russa de 1917. De novo, como resposta a essa nova sublevação popular, temos uma revolução passiva. Nessa nova onda de revolução passiva, que incorpora da revolução popular sobretudo elementos de economia programática, Gramsci vê duas expressões: o "americanismo" (que ele crê corretamente ser algo com grande potencial de expansão) e o fascismo (que lhe parece um fenômeno localizado). E ele via o americanismo como um fenômeno expansivo porque, neste mesmo momento, ele estava convencido de que a revolução russa e a sociedade que ela havia gerado estavam bloquedas pela "estatolatria". Mas aqui já estamos diante de muitas questões complexas da análise dos Cadernos. Aliás, é simplesmente fantástico que um homem preso desde 1926, escrevendo entre 1929 e 1935, um homem que se considerava membro da Terceira Internacional, no exato momento em que esta dizia (em função da crise de 1929) que o capitalismo estava ruindo, estava experimentando sua crise terminal, escrevesse nos seus apontamentos carcerários: "Nada de crise terminal: o capitalismo está sofrendo uma metamorfose de época, o americanismo, que tende à universalização, enquanto o fascismo é um fenômeno localizado". Quem mais disse isso, na época?

A grande questão é: estamos vivendo uma era de revolução passiva ou de contra-revolução? Ou seja, os processos que o capitalismo 
no mundo está experimentando hoje - a financeiração, a chamada globalização, a desconstrução do Welfare State, isso que estamos atravessando no Brasil - são expressões de revolução passiva ou são pura e simplesmente uma contra-revolução? Entre os dois conceitos há uma diferença grande. Diferente da contra-revolução, a revolução passiva introduz transformações, leva em conta demandas dos "de baixo": a classe dominante dá os anéis para não dar os dedos. Exemplo claro de revolução passiva, como mostraram bem Christine Buci-Glucksman e Göran Therborn no seu livro sobre o "desafio social-democrata", publicado no início dos anos 80, é o Welfare State. Tendo a considerar o que está acontecendo hoje, com o thatcherismo e o reaganismo, com o neoliberalismo, mais como uma contra-revolução (melhor seria: uma contra-reforma) do que uma revolução passiva. Uma revolução passiva tem como precondição que a classe dominante se sinta ameaçada, como se sentiu depois dos jacobinos, dos bolcheviques, da Segunda Guerra Mundial, de maio de 1968 em Paris e do Autunno Caldo na Itália. Não é o caso hoje. O movimento dos trabalhadores vive uma correlação de forças adversa e burguesia tem se aproveitado disso para fazer uma contra-reforma. Mas, esse é um tema que deixo aberto para novos debates.

$* * *$

FÁBIO KONDER COMPARATO — Na intervenção de Octavio Ianni eu vejo duas questões fundamentais. Uma delas me parece que foi apresentada de maneira um tanto desviante, mas a outra é muito certeira no seu objetivo.

A crítica é que nós não respondemos ao tema do seminário: como pensar? Mas a sugestão feita por Octavio Ianni, a meu ver, não é sobre como pensar mas sobre em que pensar como solução. O como pensar é simplesmente a discussão de um método, e eu diria que o método que devemos usar é, em relação a esses redescobridores do Brasil, o mesmo método que eles usaram em relação aos seus antecedentes. Temos que tomar deles o espírito crítico, separar nos autores passados o joio do trigo e sublinhar a especificidade da realidade nacional - é só isso.

Foi dito que eles apresentaram "soluções derrotadas". A meu ver isso não significa nada, porque esse tipo de raciocínio é de característica americana, ou seja, a sociedade está dividida entre losers and winners e o fato de estarmos do lado dos losers significa que nós erramos. Não é verdade. Existe uma diferença fundamental entre a técnica e a ética. Eles 
poderão ter ganho na base da técnica, mas eticamente eles foram destruidores daquilo que há de mais importante na humanidade, que são os valores da liberdade, da igualdade e da solidariedade.

De qualquer maneira, fica o desafio: o que pensar como solução. Para esboçar uma resposta a isso precisamos entrar no segundo questionamento de Octavio Ianni, que a meu ver é muito importante. Houve, de fato, grandes mudanças e mudanças recentes. E essas grandes mudanças se deram no nível do Estado e no nível das classes dominantes. Sabemos que na história brasileira o Estado sempre foi muito mais importante do que a sociedade civil. Todas as transformações no campo social e econômico foram pilotadas pelo Estado, não foram transformações de baixo para cima. Dois exemplos: a eliminação do trabalho escravo e a industrialização. Ao contrário daquilo que uma certa historiografia nos vem apresentando há décadas, a eliminação do trabalho escravo foi obra do governo imperial, não foi o resultado do trabalho dos abolicionistas. As três grandes etapas da eliminação do trabalho escravo, desde a primeira e fundamental, a proibição sob penas criminais do tráfico negreiro em 1850, passando pela Lei do Ventre Livre em 1871 e a Lei dos Sexagenários em 1886, foram leis votadas no Parlamento do Império. Todas essas leis foram encarniçadamente combatidas pela classe dominante naquela época. Por exemplo, às vésperas da votação da Lei do Ventre Livre uma associação que reunia os grandes latifundiários escravistas de Paraíba do Sul, na Província do Rio de Janeiro, dizia claramente que o Brasil estava caminhando a passos largos para a ruína, uma vez que o que a lei estava pretendendo era uma verdadeira violação da natureza: colocar a idéia de direito na cabeça do escravo. Há aqui até um desafio à teoria marxista: como é possível que a classe dominante tenha deixado que o governo imperial realizasse isso? É porque o governo imperial tinha na Assembléia do Império a maioria, e a maioria era composta de funcionários públicos e até de juizes de direito.

Esse Estado forte foi depois o responsável pela industrialização. Marco Aurélio Garcia lembra que, depois da crise de 29, Argentina e Brasil seguiram rumos opostos. A Argentina reforçou a sua organização agropecuária e, portanto, a sua dependência em relação à Europa, notadamente a Inglaterra, e o Brasil caminhou para a industrialização. Essa industrialização foi feita inteiramente pelo Estado. A classe industrial brasileira é uma criação do Estado. Hoje estamos, pela primeira vez na nossa história, com o Estado em frangalhos. A privatização, a desregulamentação, o enxugamento da máquina administrativa, o financiamento das despesas públicas 
mais por empréstimos do que por tributos tornaram o Estado brasileiro uma sombra do que ele foi, e o que se pergunta hoje é se ainda é possível restabelecer um mínimo de força no nível estatal.

A segunda grande transformação, que também me parece irreversível, é a desnacionalização das classes dominantes. Quando se iniciou a propaganda em torno da privatização os empresários nacionais estavam eufóricos, porque achavam que só eles iriam abocanhar as grandes empresas estatais. Eles ficaram, talvez, com 5\% das empresas privatizadas, não mais do que isso. Ora, não é preciso ser um analista muito profundo para prever as consequiências disso, já não digo no plano econômico mas no político. As próximas eleições presidenciais vão ser decididas, em grande parte, com a influência deste setor estrangeiro das classes dominantes.

Diante disso, qual a proposta? Evidentemente tentar esboçar soluções aqui é uma ousadia. Eu diria, no entanto, que, em primeiro lugar, é impossível voltar ao Estado antigo, esse Estado, como disse o Raymundo Faoro, do estamento burocrático. Isso terminou e não existirá mais. É preciso então pensar num novo tipo de organização política e esse novo tipo de organização política deve superar o tradicional confronto que vem desde Hegel, entre Estado e sociedade civil. A superação dessa dicotomia vai no sentido da construção de um Estado participativo. Já existem alguns sintomas disso. Mais do que sintomas, existem experiências, e experiências que têm tido um resultado importante, embora em nível meramente municipal. As diretrizes orçamentárias podem e devem ser decididas pelo povo diretamente. Decidir as diretrizes orçamentárias significa decidir as políticas econômicas e sociais. Hoje, a realização dos direitos econômicos e sociais - o direito à saúde, à habitação, à previdência social - passa por uma determinação de meios financeiros, e esses recursos são votados no orçamento. Se o orçamento deixar de ser decidido unicamente por órgãos do Estado, e passar a ser decidido quanto às suas diretrizes pelo próprio povo, já é um direcionamento importante.

A segunda proposta de superação dessa dicotomia Estado/sociedade civil é recriar um poder planejador, mas um poder planejador com participação popular. Em nenhuma Constituição atual existe a previsão do poder de planejamento, e no entanto, até o advento do neoliberalismo isso já foi amplamente praticado, no Estado japonês por exemplo. É preciso criar um poder planejador que não seja apenas burocrático, e que conte com a participação do povo. Nesse sentido, a nossa modestíssima Constituição de 88 já dá algumas diretrizes, que obviamente até agora não foram implementadas, mas são importantes. O plano nacional de educação 
e o plano nacional de saúde deveriam contar com a participação dos setores do povo que têm ligação direta com essas atividades e com a organização de políticas públicas. É muito pouco, reconheço, mas é apenas uma indicação do rumo que deveríamos seguir.

$* * *$

FRANCISCO DE OLIVEIRA - Nesta etapa final do nosso debate eu não vou entrar nos numerosos pontos interessantes para discutir e vou limitar-me a esclarecer, contra as dúvidas aqui levantadas em alguns momentos, a minha posição em relação aos "clássicos" ou "demiurgos" do pensamento brasileiro. Certamente é preciso repensar o Brasil, mas não ao ponto de perder a especificidade, o que tornaria inútil qualquer esforço teórico maior. O sentido exato da minha intervenção não foi discutir exatamente o que pensar nem resgatar demiurgos para repeti-los, mas muito ao contrário, resgatar para não repeti-los. 



\section{ENCERRAMENTO}

MARCO AURÉLIO GARCIA - Ao longo de 25 anos o CEDEC pensou o Brasil e nesse dia e meio resolveu terceirizar essa tarefa, seguindo a onda moderna, em um grupo de intelectuais que compareceram aqui e que abrilhantaram esse seminário. Nós, os terceirizados, queremos, na condição de amigos e companheiros de viagem do CEDEC, felicitar essa instituição pelo seu primeiro quarto de século de existência. 